\title{
English Teachers' Reflections and Lessons Learned in Language Teaching During COVID-19 Pandemic
}

\author{
Komilie Situmorang ${ }^{1,2}$, Santa M Pramusita ${ }^{1}$, Dwi Y Nugroho ${ }^{1}$ \\ ${ }^{1}$ Universitas Pelita Harapan \\ 2Email: komilie.situmorang@uph.edu
}

\begin{abstract}
This study seeks to find out the English teachers' reflections and lessons learned in language teaching during the pandemic. The method used was a guided narrative frame in which the teachers from the suburban wrote down their feelings and lived experiences. The data was analysed using thematic analysis and presented in themes. The findings indicate that the teachers found it challenging at the beginning of their online teaching. Both the teachers and students faced problems including economic situations, tech problems and mental struggles. Interestingly, this finding is similar to the outskirt teachers and students'problems. Besides, the teachers have learned the most vital things during their language teaching in the early year of the pandemic. They continuously shift their teaching strategies, provide personalised feedback to support the students' engagement, and become adaptable teacher-learners. Suggestions are provided for both teachers and policymakers.
\end{abstract}

Keywords: English Teachers, Lessons learned, Online Learning, Reflections

\section{INTRODUCTION}

Rapid and unanticipated change in English language teaching (ELT) has been the result of Covid-19 in the past year. The teachers and students are now housed for an unknown period due to the physical distancing due to the rapid infections. The government has long before echoed the slow changing of learning into online learning but not all the teachers are yet ready to embrace the technology. Although many studiespromote the use of technology in enhancing language learning(Harmer 2001; Eaton 2010; Gilakjani 2014), teachers do not seem to move an inch to utilise the technology in the classroom until Covid-19 sweeps.

The covid-19 outbreak has brutally forced the teachers to conduct class remotely as the classes are shut down. The teachers are crawling and expected to think quickly of how to keep the class going through the online platforms. Starting from very low-tech platforms like WhatsApp to contact students and give assignments to interactive platforms as Zoom and Google meet, teachers adapt to the new situation. Instead of asking the students questions in class, teachers now ask the students to click on 'raise hand' 
in Zoom video conferencing. Common language teaching, usually based on vocabulary, grammatical exercise, and reading comprehension, is no longer relevant. Besides, the need for language evaluation has also been paramount howthe teacher is supposed to assess the students remotely.

Although there has been a slow introduction to blended learning(Gonzalez and St.Louis 2018), there is yet limited research onthe pandemic situation because it is a forced Majeure. Previous studies in the field of online learning during the COVID-19 outbreak has shown some striking findings. Cao et al.(2020)) finds that the sudden change from faceto-face learning into fully online education affects the students' development. Another study recently done in a rural area of Indonesia is by Atmojo and Nugroho (2020). By employing a qualitative study, they collected the written reflection from 16 participants and proceeded to interview 5 of them because they gave exciting reflection. The findings uncover that the unavailability of the money to buy internet data, the mountainous areas with limited coverage, and the students' unpreparedness for learning online activities are the triggers to skip the class. Reflecting on what Atmojo and Nugroho (2020) have uncovered, this research will investigate other areas of Indonesia to offer different perspectives of what challenges are faced by the teachers from suburban.

There has been a lot of studies that have discussed the challenges faced by teachers in language teaching (Iswati 2021; Tukan 2020; Rosalina, Nasrullah, and Elyani 2020; Efriana 2021; Lie et al. 2020; Yuzulia
2021; Nugroho, Ilmiani, and Rekha 2021). Since Covid-19 mainly triggers the implementation of technology in language teaching, most previous studies present the challenges in teaching using the technology. Johnson et al.(2016) introduce the technology challenges in three constraints; access, training, and support. The study has found that many schools and students have no adequate accessto computers to the internet connection. The teachers also have never received sufficient professional training on using the new technology, so they cannot use it to its fullest potential. Ertmer et al. (2012) mention that technology is not implemented because of the professional development and training absence. Finally, there has not been adequate technical and administrative support available.

Studies from various countries have reported similar problems. Binod(2015) finds that rural area in India has less ambience and affordability in learning facilities, making it difficult to have high expectations of the result of the learning. The rural area is lack facilities and lack training. Besides, the overcrowded class (Lie 2007) has been one issue in designing remote learningto increase the engagement in the many numbers of the students in an online platform and what evaluation should be given. The teachers also are forced to think about their students' conditions. On one side, the teachers may only have a basic theory and practical application skills, thus strugglingto use technology to reach out to the students (Littlewood 2007). On the other side, they also need to think about their students' means of technology. What technologies are available to their students to make learning happens. 
Teachers' beliefs and attitudes are one of the most crucial factors in determining their challenges in language teaching Johnson et al. (2016). Their beliefs and attitudes will strongly influence how theylead the students during the Covid-19 outbreak. A positive attitude most likely optimisesusing any means of technology in keeping the class going remotely. Teachers who are in the rural area sometimes find themselves without sufficient skill in English (Garton, Copland, and Burns 2011)as well as in using technology in their language teaching. Therefore, they are not confident and cannot control the class when using the technology. Those who believe that they lack skills and knowledge may end up using technology that they are comfortable with or, at worst, postpone until they are skilful enough.

The covid-19 outbreak has affected all sectors of education all over the world. In response to school closures, many language institutions like British Council, TESOL.org, and Pearson, book publishers like Springer even Amazon have offered supports to help teachers and students do remote learning. A lot of free ideas, guidance and resources are provided online for free. Free webinars from local to international organisations are also free to create the teaching and learn online classes. As the outbreak has now closed 177 countries leaving more than 1 billion students studying at home, language learning has experienced remodelling in its delivery.

Although it is salient to the researchers that there have been many online free webinars in helping teachers cope with the technology, it is debatable that the teachers face mounts of challenges of diving into the world of remote learning independently. In this respect, it is interesting to know what reflections and what lessons learned through this past year by teachers. This research is prominent as covid-19 has impacted the future of language teaching.

\section{METHODS}

This research is design in a qualitative framework. The sampling used was a total sampling of 30 secondary English teachers under the collaboration with the private university in which the researcherswork. However, due to the saturation of the data, only half of the participants' data were analysed. Furthermore, data saturation which is defined as the turning point in coding when no new codes appear in data (Urquhart 2013), resulted in only 15 samples.

Data collection was done through a narrative frame. A narrative frame is a guided story template structured in a skeletal form consisting of incomplete sentences and black spaces thatproduce a coherent story by filling in the spaces according to their reflections on the events (Barkhuizen 2016). This instrument was structured with dimensional space narrative, which seeks to explore how they feel, hope, react, and think (interactions), what they see now and then (continuity) and how they position themselves through time and space (situation) (Creswell 2012). Therefore, the participants were free to write down their feelings without feeling intimidated. The data was analysed using thematic analysis inductively, where coding and the development of the theme were generated from the data (Braun and Clarke 2006). The process went through familiarising the data, coding, establishing initial themes, naming themes, and writing up.

\section{2}




\section{FINDINGS AND DISCUSSION}

The findings are presented within the themes and followed by the discussion.

\subsection{Findings}

\subsubsection{Teachers' Reflections}

\section{a. Economic Situation}

The findings indicated that both students and teachers stumbled over the economic condition when it came to online learning. Furthermore, the participants in this research exposed that Zoom and Google meet were not easy because the students did not have internet data and did not own media like laptops or suitable mobile phones.

Some of my students could not join the meeting because of the limited internet data. Zoom app needs a strong network and spends a lot of data (Participant 2)

Some of the students did not have cell phones or smartphones. They were still borrowing their parents' phones. When I gave them tasks, their parents complained that the task was overwhelming (Participant 3)

My students' parents visited me and told me that they did not have money to buy internet data and asked me to give the material using the written form (Participant 6)

I must manage my own money because to operate online learning. Ineeded good internet access (Participant 7)

The students did not have the required electronic media needed for online learning (Participant 14)
The excerpts showed that it had not been easy to shift to online learning because the students and the teachers were not ready with the internet and laptop to support online learning.

\section{b. Tech-problem}

In thefollowing reflections, teachers expressed that the students and the teachers were challenged to use the tech and suitable apps in online learning during the early pandemic. As they were used to the variety of face-to-face methodology, they were left in anxiety when shifting to online learning. Students and teachers equally faced this condition.

My students were not familiar with gadgets and online learning... I must read more about how to use digital apps (Participant 13)

I was confused about operating digital media because I never used them before (Participant 1)

I did not know how to use Zoom, Google form and quiz. I even rarely used PowerPointslides before the pandemic (Participant 2)

Students did not have an email address. Some of them forgot their email, so I must ask them to make a new email... The students could not hear my voice as they did not know how to click audio in Zoom. (Participant 11)

I had to teach other teachers to use the apps and, at the same time focusing on my students. I worked twice (Participant 4)

These findings showed that students and teachers were all immersed in the unknown world when it came to online learning. None of them was ready in terms of the use of tech. 
Komilie Situmorang, Santa M Pramusita, Dwi Y Nugroho

English Teachers' Reflections and Lessons Learned in Language Teaching During COVID-19 Pandemic

DOI: https://doi.org/10.31605/eduvelop.v5i1.1111

\section{c. Mental struggles}

The following findings regarding the teachers' reflections were the mentality regarding online learning. As the students were remotely placed from their classroom and seated at their homes, mental problems did arise, including shock, tiredness, integrity, and home situation.

My mentality was overwhelmed, and it was difficult to accept this kind of situation. Teaching from home was boring, and I missed my students (Participant 3)

I typically could not see the screen for a long time. Now, I had to read thetasks slowly as they collected them in Word and Pdf doc (Participant 12)

My students did not focus on the material. Theywere busy with their social media like WhatsApp and Instagram (Participant 15)

When I gave the students assignment, they would just cheat on their friends or copied the answers from the internet. They were increasingly lazy in reading and losing self-confidence (Participant 5)

I found my students lost focus as a baby was crying in his house (Participant 7)

These excerpts showcased that learning online from home due to pandemics had posed a mental attack to both teachers and students. The data indicated pandemic and home learning situations contributed to the failure in maintaining their previous principles.

\subsubsection{Lessons Learned}

\section{a. Shifting Learning Strategies}

One year of having a roller-coaster teaching situation through the pandemic, the teachers have survived the challenge in online learning, and they learn to cope with their current situation. The teachers have reflected through the first year of the pandemic and now apply various strategies in their classes. These shifts include the extended deadlines, variations of material delivery, availability of learning videos, and the utilisation of social media.

I give the task, but I do not push them to do it perfectly. Instead, I give them time to do it at the weekend to manage their time wisely (Participant 10).

I use various app and platforms such as YouTube. I ask them to make conversation and order them to share it in their account (Participant 3).

I design my class in a group and open to questions. In addition, I do virtual classes and even visit their house based on the health protocol (Participant 14).

I trigger the students' learning with independent and discovery learning by providing them with relevant resources, worksheets, and guidelines. I organisethe class discussion, student'spresentation, and online games (Participant 7)

I give them a topic and ask them to search for a case related to the topic and find the solution. I utilise several interesting online programs when giving exercises to students (Participant 9) 
These excerpts represented the ways how participants have been varying their learning strategies after the pandemic. The teachers had transformed themselves as they found failure at the beginning of online learning. They also found ways of how to keep the learning going and maintaining the fun situation. They no longer focused on achieving the lesson plan but fostering engagement.

\section{b. Personalised Feedback}

The students and teachers were studying and teaching from home, a new media to facilitate communication was generated. Most of the teachers chose to organise a WhatsApp group so students could always reach them out. Some other used the help of Line, while others used Google Classroom. However, though the media varied, the purpose is for them to be easy to give feedback. This feedback is paramount because the students needed to know whether they checked their tasks. Giving feedback had guaranteed the students that their teachers were available and at the same time got encouragement from the feedback provided by their teachers.

I make a WhatsApp group communicate with each other and ask my opinion on their tasks (Participant 3).

I comment on the video. Then, after my feedback, they can upload their video on their Instagram to get like and comment from others (Participant 8).

I give scores to my students based on their efforts and stay online 24 hours (Participant 11).

I give them appreciation by congratulating them and ask them to teach the others (Participant 13).
I put the task in my google classroom and return it with a private comment, or I give them direct feedback during the online session (Participant 7).

Through online learning, the teachers had been committed to giving more personalised feedback to their students. The teachers voluntarily used their time to keep supporting their students.

\section{c. Teacher-learner}

A year of uncertainty has transformed the teachers to keep on learning and exercising their skills through online learning. They have learned a lot and reflected on how their roles were vital for their students' growth. As a result, they have found ways to keep up with online learning and perform better. They know they must be creative, flexible, and eager to study.

We have to be as creative as possible in giving the lesson to our students (Participant 2).

Be innovative and brave to take down all the challenges as we model our students (Participant 11).

I can be more creative, be more confident, and give the students the best (Participant 15).

I find that our education system might be too old, so it is challenging to deal with a situation like this. However, this situation has forced the teachers to improve their digital ability, which might be helpful for the new future education system (Participant 10).

I learn to always eager to study new things. Now, I have found so many digital learning platforms which I can use in my class. The teacher must be adaptable to any situation functioning as a good 
and wise teacher who can create a pleasant atmosphere regardless of the situation (Participant 9).

The participants are optimistic about their current situation as they are striving to be more creative and innovative in delivering material through online learning. These findings prove that teachers never stop learning.

\subsection{Discussion}

The findings of this study have highlighted two main essential factors, namely teachers' reflections and lessons learned through online learningdue to pandemic situations. The first main factor reflections has been about how the first year of a sudden shift to online learning impacted language learning in schools. Three themes arise from the teachers' story through the narrative frame, including 1) economic situation, tech problem, and mental struggles. The second main factor - lessons learned has been about the take-away the teachers have reaped through online learning. The teachers know a lot of new things from reflecting on past situations. Similarly, three themes are generated from the teachers' story, namely 1) shifting learning strategies, giving personalised feedback, and becoming teacherlearner.

The first factor - reflections generated a quite surprising inding regarding The implementation of Online learning. This Study bas conducted in the sub-urban of the Tangerang, which si St The heart of The region. As found in this study, The Economic situation hinders online learning. Many students do not have internet data Ana enough resources like laptops Ana phones do conduct online learning. This situation si on different do the study done in The outskirt of Indonesia, as reporter by a previous study (Atmojo and Nugroho 2020; Nugroho, Ilmiani, and Rekha 2021). Another similarity is that the students' phones are a family asset, so learning is becoming more complex (Rosalina, Nasrullah, and Elyani 2020). The only difference is that the suburban has enough network they need, unlike those in suburban who live in mountainous areas. In this case, it is a universal problem in Indonesia. Therefore, we cannot generalize that students in sub-urban have better economic situations than those in the outskirt.

Besides, the tech problem is also not uncommon in this study. Almost all the participants in this study complain regarding using technology to teach in an online class. They admit that before the pandemic, they hardly use even PowerPoint slides when teaching. Therefore, when faced with the face-to-face class shutdown, they must move to Zoom and Google Meet, which is strange. Some teachers cannot deliver the material because Zoom is a whole new world. Not only the teachers but also the students are overwhelmed. They could not speak or listen to their teacher because they do not know where the audio button to turn on the audio. These situations are portrayed well in Tukan's study (2020), in which the teachers in Yogyakarta, Gunungkidul, Magelang, and Kebumen also face a similar problem in delivering the material. Therefore, even students and teachers in sub-urban are not tech skilled. They experience a similar problem with those who are in the outskirt of Indonesia.

Mental struggles are portrayed as the most significant setback in this study. Students and

\section{6}


teachers are shocked due to the sudden shift. The absence of internet data and the tech needed make both teachers and students struggled mentally. How to deliver material, provide feedback, do tasks, and learn from the home situation have burdened them at the beginning of the teaching and learning from home. As a result, both teachers and students cannot focus on delivering the material. The teachers are overwhelmed with the new workload and longed for a class situation. They also need to adjust to the latest activities, such as checking tasks through the online platform, as they take time(Nugroho, Ilmiani, and Rekha 2021).

Meanwhile, the students find it hard to study without control. Learning at home alone leads them to play with gadgets, even during the online zoom video call with their teachers (Efriana 2021). They also lost interest in doing their task. Instead of working independently to do their task, they prefer to copy other's tasks or even from internet sources. In addition, the home situation is not conducive for studying. A teacher in this study reveals that she could hear noises such as a baby crying when having the online session. This condition demotivates students and is a challenge for online learning (Rosalina, Nasrullah, and Elyani 2020).

Thankfully, the past year of the pandemic has been a lesson to reflect on for the teachers. They have grown to embrace the situation as today. Online learning is still the only way for studying. Besides, the teachers have been provided with many free online resources that they could learn to support the classroom online. Though some teachers do not have the privilege to enjoy the trainingas many teachers, they all have tried their best to keep on the learning going. Some even have been reported to visit the students physically to their houses by paying attention to the health protocol. The most important thing is that all teachers are learning and progressing.

In this study, teachers are found to have learned to shift their learning strategies to fit the online learning needs they have reflected in the past year. The communication which is hindered by spaces is facilitated by opening WhatsApp and Line Group. The learning method is adjusted by making group discussions, given extended deadlines to the tasks, and offering fewer tasks but more challenging. One teacher is found to bring the students into a discovery learning where they are asked to find a case related to the topic and think about the solution to solve a problem. The point is that they are giving doable tasks but with ore impact (Iswati 2021). What teachers do is exactly the turning point in online learning. They are not stuck with their previous offline view of the perfect classroom. Still, they are transforming themselves, their classroom, and their students through communicating, giving instruction, using various platforms, online grouping and becoming more flexible with the assignment. The teachers are not solely after the lessons' objectives but the engagement of the students.

Besides, the teachers have learned a new way of giving feedback to their students. Rather than emphasizing the students' achievement, they now look at the students' participation and provide more personalized feedback. In this study, the teachers are found to leave positive comments on the students works, be available in the group to answer students' 
questions and praise them for what they have done. This act is arguable an increased awareness from the teachers of how important the feedback is for their students. The teachers consistently support the students through some of the sessions are done through the asynchronous mode. The teachers have used personalized feedback to strengthen the bond between the teacher and the students, although they no longer can meet physically. It is an assurance that learning is going and that their teachers know the students. The very same finding is also showcased by ESP teachers, who also transform themselves to give different learning strategies, thus contributing to a more effective learning situation(Iswati 2021; Lie et al. 2020). Therefore, teachers should maximise their efforts to provide feedback, not the ones emphasizing the achievement but the reinforcing feedback.

Lastly, the students are looking to their teachers as their role models. Teachers are the main actors in the classroom that direct the mood of the class. Therefore, teachers need to be creative, innovative and be confident about their classroom. They should be preparing their class whole-heartedly like they are going on a show. The participants in this study agree that they have to act as teacher-learner who are ready to learn new things every day. Besides, they must be adaptable to many situations. Therefore, instead of complaining about the absence of offline classes, they can do better by establishing a pleasant atmosphere in the online learning situation. Further, as the teachers are forced to be creative, they have realized that the current situation has been preparing them for future possibilities in language teaching. These teachers are in the middle of shaping the future education faces where online learning might not be the option but the primary way of teaching.

Though the pandemic has been drawing tears from both teachers and learners at the beginning of the online learning implementation, it is safe to say that both have now get used to it and live with it. The teachers mainly have reflected and learnt a lot. They have also embraced the situation by not giving up on the economic, tech, and mental struggles they faced. As a result, they change their learning styles, give personalized feedback, and keep learning each day and every day. They also gain confidence and, at the same time, enhance their commitment, raise their awareness and competence (Lie et al. 2020; Iswati 2021). The teachers are professionals in the show each day, and they know what they do.

\section{CONCLUSION AND SUGGESTION}

The study has been about the teachers' reflections and lessons learned during the early year of pandemic situations where the participants are teachers from the suburban. The findings, however, reveal that there are no significant differences between the teachers in the suburban and the outskirt as previous study and the current study show that their problems Centre around the economic situation, tech-problem, and mental struggles.

However, the teachers have indeed transformed themselves through the ups and downs of online learning. Failing with one teaching method does not stop teaching. Instead, they change their learning strategies to meet the students need and support them to get the best out of the learning. They also give personalized feedback that aims to embrace 
the students' engagement rather than achievement. Lastly, the teachers position themselves as learners ready to adapt to any possibilities to create a creative, fun, and engaging classroom.

Therefore, in light of the findings, which also radiate other studies' findings, this study provides suggestions to two main actors in the education system, including the teachers and the policymakers. The teachers have done their best through this time by learning how to organize their class. They deserve applause. In this case, they are expected to keep on learning so they can better support their students. Therefore, it is highly suggested that they keep following the available training to help them with more updated learning styles. On the other hand, the policymakers need to provide training that allows the teachers to organize the classes and give the media they need to conduct online classes because many teachers have to buy their laptops. Best education quality comes from the best preparation.

\section{REFERENCES}

A Lie. 2007. "Education Policy and EFL Curriculum in Indonesia: Between the Commitment to Competence and Quest for Higher Test Scores." TEFLIN Journal 18 (1): 1-14.

Atmojo, Arief Eko Priyo, and Arif Nugroho. 2020. "EFL Classes Must Go Online! Teaching Activities and Challenges during COVID-19 Pandemic in Indonesia." Register Journal 13 (1): 49-76. https://doi.org/10.18326/rgt.v13i1.4976.
Barkhuizen, Gary. 2016. "Narrative Approaches to Exploring Language, Identity and Power in Language Teacher Education." RELC Journal 47 (1): 25-42. https://doi. org/10.1177/0033688216631222.

Binod, Mishra. 2015. "Innovative Ways of English Language Teaching in Rural India through Technology." International Journal of English and Literature 6 (2): 38-44. https://doi.org/10.5897/ IJEL2014.0686.

Braun, Virginia, and Victoria Clarke. 2006. "Using Thematic Analysis in Psychology." Qualitative Research in Psychology 3 (2): 77-101. https://doi. org/10.1191/1478088706qp063oa.

Cao, Wenjun, Ziwei Fang, Guoqiang Hou, Mei Han, Xinrong Xu, Jiaxin Dong, and Jianzhong Zheng. 2020. “The Psychological Impact of the COVID-19 Epidemic on College Students in China." Psychiatry Research 287 (May): 112934. https://doi.org/10.1016/j. psychres.2020.112934.

Creswell, J. W. 2012. Qualitative Inquiry and Research Design: Choosing among Five Traditions. Thousand Oaks, CA: SAGE Publications, Ltd.

Eaton, S. E. 2010. Global Trends in Language Learning in the Twenty-First Century. Calgary, Canada: Onate Press. https://files.eric.ed.gov/ fulltext/ED510276.pdf.

Efriana, Leli. 2021. "Problems of Online Learning during Covid-19 Pandemic in EFL Classroom and the Solution." JELITA: Journal of English Language Teaching and Literature 2 (1): 38-47. 
Ertmer, Peggy A., Anne T. Ottenbreit-Leftwich, Olgun Sadik, Emine Sendurur, and Polat Sendurur. 2012. "Teacher Beliefs and Technology Integration Practices: A Critical Relationship."Computers \& Education 59 (2): 423-35. https://doi.org/10.1016/j. compedu.2012.02.001.

Garton, S., F. Copland, and A. Burns. 2011. "Investigating Global Practices in Teaching English for Young Learners.” Birmingham.

Gilakjani, Abbas Pourhosein. 2014. "A Detailed Analysis over Some Important Issues towards Using Computer Technology into the EFL Classrooms." Universal Journal of Educational Research 2 (2): 146-53. https://doi. org/10.13189/ujer.2014.020206.

Gonzalez, Dafne, and Rubena St.Louis. 2018. "Online Learning." In The TESOL Encyclopedia of English Language Teaching, 1-6. Hoboken, NJ, USA: John Wiley \& Sons, Inc. https://doi. org/10.1002/9781118784235.eelt0423.

Harmer, Jeremy. 2001. "Book Review: The Practice of English Language Teaching." RELC Journal 32 (1): 135-36. https://doi. org/10.1177/003368820103200109.

Iswati, Luluk. 2021. "When Teaching Must Go on: ESP Teachers' Strategies and Challenges during COVID-19 Pandemic." Eralingua: Jurnal Pendidikan Bahasa Asing Dan Sastra 5 (1): 36. https://doi.org/10.26858/eralingua.v5i1.16196.

Johnson, A. M., M. E. Jacovina, D. E. Russell, and C. M Soto. 2016. "Challenges and Solutions When Using Technologies in the Classroom."
In Adaptive Educational Technologies for Literacy Instruction, edited by S. A. Crossley and D. S. McNamara, 13-29. Taylor \& Francis.

Lie, Anita, Siti Mina Tamah, Imelda - Gozali, Katarina Retno Triwidayati, Tresiana Sari Diah Utami, and Fransiskus - Jemadi. 2020. “Secondary School Language Teachers' Online Learning Engagement during the Covid-19 Pandemic in Indonesia." Journal of Information Technology Education: Research 19: 803-32. https://doi.org/10.28945/4626.

Littlewood, William. 2007. "Communicative and Task-Based Language Teaching in East Asian Classrooms." Language Teaching 40 (3): 243-49. https://doi.org/10.1017/S0261444807004363.

Nugroho, Arif, Dwi Ilmiani, and Agnira Rekha. 2021. "EFL Teachers' Challenges and Insights of Online Teaching amidst Global Pandemic." Metathesis: Journal of English Language, Literature, and Teaching 4 (3): 277. https://doi.org/10.31002/metathesis.v4i3.3195.

Rosalina, Elsa, Nasrullah Nasrullah, and Eka Puteri Elyani. 2020. "Teacher's Challenges towards Online Learning in Pandemic Era." LET: Linguistics, Literature and English Teaching Journal 10 (2): 71. https://doi.org/10.18592/ let.v10i2.4118.

Tukan, Fransiska M. Ena. 2020. "Challenges and Strategies Using Application in Online Teaching during Pandemic." English Education: English Journal for Teaching and Learning 8 (2): 138-54. 
Urquhart, Cathy. 2013. Grounded Theory for Qualitative Research: A Practical Guide. 1 Oliver's Yard, 55 City Road London EC1Y 1SP: SAGE Publications, Ltd. https://doi. org/10.4135/9781526402196.
Yuzulia, Irza. 2021. "The Challenges of Online Learning during Pandemic: Students' Voice." Wanastra: Jurnal Bahasa Dan Sastra 13 (1): 08-12. https://doi.org/10.31294/w. v13i1.9759. 